М. Н. Скаткина. - М. : Просвещение, 1982. - 319 с. З. Краевский В. В. Проблемы научного обоснования обучения (Методологический анализ) / Володар Викторович Краевский. - М. : Педагогика, 1977. - 264 с. 4. Лозова В. І. Теоретичні основи виховання і навчання: [навч. посібник] / В. І. Лозова, Г. В. Троцко. - Х. : ОВС, 2002. 400 с. 5. Малафіїк І. В. Дидактика: [навч. посібник] / Іван Васильович Малафіїк. - К. : Кондор, 2005. - 398 с. 6. Эльконин Б. Д. Понятие компетентности с позиций развивающего обучения / Б. Д. Эльконин // Современные подходы к компетентностно-ориентированному образованию : [материалы семинара]. - Самара : Профи, 2001. - С. 4-8. 7. Ягупов В. Дидактичні поняття: «навчальний процес» чи «процес навчання»? / Василь Ягупов// Рідна школа. - 2000. - № 2. - С. 16-19. 8. Якса Н. В. Основи педагогічних знань : [навч. посібн.] / Наталія Володимирівна Якса. - К. : Знання, 2007. - 358 с.

УДК 378.016:91

Олена Ганчук

\title{
ОСОБЛИВОСТІ КЛАСИФІКАЦЇ̈ НАВЧАЛЬНИХ ЕКСКУРСІЙ 3 ГЕОГРАФІЇ, ЩО ВИКОРИСТОВУЮТЬСЯ У ПРОЦЕСІ ПІДГОТОВКИ МАЙБУТНІХ УЧИТЕЛІВ
}

Ганчук О. В. Особливості класифікації навчальних екскурсій $з$ географії, що використовуються у процесі підготовки майбутніх учителів.

У статті розглянуто різні класифікації навчальних екскурсій. Подано авторську класифікацію навчальних екскурсій, де види екскурсій співвідносяться 3 формами групової пізнавальної діяльності студентів на кожному етапі їхнього професійного становлення.

Ключові слова: екскурсія, навчальна екскурсія, групова робота, пізнавальна діяльність.

Ганчук Е. В. Особенности классификации учебных экскурсий по географии, которые используются в процессе подготовки будущих учителей.

В статье рассмотрены различные классификации учебных экскурсий. Представлена авторская классификация учебных экскурсий, где виды экскурсий соотносятся с формами групповой познавательной деятельности студентов на каждом этапе их профессионального становления.

Ключевые слова: экскурсия, учебная экскурсия, групповая работа, познавательная деятельность.

Ganchuk O. V. Features of classification of educational excursions from geography, that is used in the process of preparation of future teachers.

The article deals with different classifications of educational excursions. The author gives her own classification of educational tours, where types of excursions correlate with forms of group cognitive activity of students at every stage of their professional development.

Key words: excursion, educational excursion, group work, cognitive activity.

Нині необхідна принципова перебудова і вдосконалення організації навчальновиховного процесу у вищих закладах освіти. Це насамперед стосується збільшення відсоткової частки тих форм навчання, які формують у студентів знання, уміння i навички, створюють умови для розвитку в них здатності самостійно добувати 
необхідні знання, приймати рішення, розв'язувати нестандартні і нетипові задачі, постійно вчитися. На наш погляд, усі зазначені вище показники вміщає в себе організація роботи студентів під час навчальних екскурсій з географії. Не менш важливим завданням є розроблення сучасних класифікацій екскурсій, які б дозволяли об'єктивно визначити рівень навченості студентів у процесі проведення екскурсій 3 географії.

Проблема організації проведення навчальних екскурсій не є новою. 3 аналізу праць просвітителів та науковців-природознавців минулого (С. Ананіна, М. Анциферова, М. Баранського, Ф. Гофмана, О. Луначарського, К. Міхна, В. Половцова, Б. Райкова, С. Тисаревського, К. Ушинського та ін.) та сьогодення

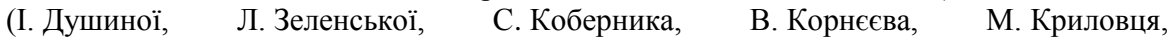
В. Максаковського, Н. Муніч, О. Надтоки, Т. Назаренко, В. Пятуніна, О. Скуратовича, О. Тімець, О. Топузова та ін.), державних документів, методичних матеріалів, передового педагогічного досвіду з'ясовано, що в поняття «екскурсія» у різні часи як і сьогодні вкладався неоднаковий, іноді навіть протилежний зміст. У цілому екскурсією (від лат. excursio - поїздка, вилазка) називають діяльність з відвідування визначних чим-небудь об'єктів (пам'ятників культури, музеїв, підприємств, місцевості тощо), форма й метод набуття знань, що проводиться, як правило, колективно під керівництвом фахівця-екскурсовода.

Meта cmammi: розглянути різні класифікації навчальних екскурсій і на основі їх узагальнення представити власну.

Екскурсія пройшла значний шлях у своєму розвитку. Поширення та вдосконалення екскурсійного методу навчання пов'язані 3 прагненням педагогів перебороти однобічність книжкового й вербального навчання. На позитивну роль екскурсій у системі навчання й виховання вказували Я. Коменський, Ж. Ж. Руссо, Й. Песталоцці, А. Дістервег та інші. Перші висловлення щодо шкільних екскурсій припадають на другу половину XVIII ст. (Н. Новіков, Ф. Янкович де Мирієво, В. Зуєв). Рекомендації проводити навчальні екскурсії містилися в Уставі народних училищ від 1786 р. і нарешті перший в Росії Університетський устав від 1804 р. пропонував улаштовувати для учнів i студентів «прогулянки в природу», на мануфактуру тощо.

У зв'язку з розробленням і поширенням ідей батьківщинознавства в 60-х рр. XIX ст. екскурсійний метод навчання пропагували К. Ушинський, Н. Вессель, Д. Семенов, В. Герд та ін.

Із другої половини XIX ст. екскурсії поступово входять у практику окремих шкіл, приватних гімназій і комерційних училищ. Наприкінці XIX - початку XX ст. розробленням питань шкільно-екскурсійної методики займалися I. Акінфієв, $\begin{array}{llll}\text { C. Аржанов, } & \text { В. Артоболевський, } & \text { Е. Звягінцев, Д. Кайгородов, } & \text { В. Половцов, }\end{array}$ Н. Тарасов та ін. У 1919 р. під редакцією Б. Райкова й Г. Боча вийшла праця «Шкільні екскурсії: їхнє значення й організація», у якій уперше були сформульовані основні принципи екскурсійної методики й розроблена система навчальних екскурсій за всіма предметами [6].

Указуючи на багатогранність екскурсійного методу, дослідники виокремили такі основні його аспекти: 1) подорожування - набуття, збагачення, розширення знань; 2) контакт із справжнім матеріалом у його природному середовищі, що вносить гостроту й інтенсивність сприйняття, піднесення благородних і чистих емоцій, високу напругу енергії у боротьбі з труднощами, прагнення до мирної перемоги над ними під час розв'язування певної навчальної проблеми; 3) можливість виявити самодіяльність, самостійність і творчість; 4) поєднання спостереження 3 «моторними елементами»; 
5) можливість отримувати знання, перебуваючи на свіжому повітрі.

Протягом ХX ст. екскурсійний метод значно збагатився досвідом передових педагогів. 3'явилися розробки й методики проведення екскурсій 3 різних географічних дисциплін - фізичної географії, економічної та соціальної, рекреаційної, які враховують профіль навчання учнів та студентів, їх вікові особливості, вимоги часу, існуючі технічні та матеріальні можливості. Ці та інші питання розкривають у своїх працях М. Баранський, І. Душина, Л. Зеленська, С. Коберник, В. Корнєєв, В. Максаковський, В. Ніколіна, В. Пятунін, О. Скуратович, О. Топузов та ін.

Навчальна екскурсія - це форма організації навчально-виховної роботи, яка дозволяє організувати спостереження та вивчення різних явищ, предметів, процесів у природних умовах, музеях, на виставках тощо. Екскурсія збагачує студентів знаннями про географічні закономірності, геокомпоненти конкретного природного чи суспільного об'єкта, матеріальне виробництво, людей праці, сучасні технології та техніку виробництва. Для студентів педагогічних ВНЗ екскурсія слугує засобом формування професійної компетентності майбутнього вчителя географії.

У науковій літературі наведена значна кількість класифікацій навчальних екскурсій. Зокрема [4]:

- за змістом - оглядові, тематичні (виробничі, біологічні, історичні, краєзнавчі, мистецтвознавчі та інші), комплексні;

- за витратами часу - короткочасні та тривалі;

- за місцем у навчально-виховному процесі - вступні (на початку вивчення теми або розділу програмного матеріалу), проміжні (у процесі вивчення теми або розділу програмного матеріалу), підсумкові (у кінці вивчення теми, розділу), а також аудиторні та позааудиторні;

- за місцем проведення - місцеві, заміські, музейні, виробничі, у природі, а також - ближні та дальні;

- за способом пересування - пішохідні, транспортні, комбіновані;

- за складом учасників - для дорослої аудиторії, дітей, місцевого населення, туристів, сільського населення, організованої групи, індивідуальних відвідувачів;

- за способом організації діяльності- демонстративні, ілюстративні, дослідницькі;

- за способом організації сприйняття екскурсійного об'єкта - телеекскурсії, наочні, заочні, віртуальні, інтернет-екскурсії.

Разом $з$ тим, під час вивчення географічних дисциплін як у школі, так і в педагогічному ВНЗ виокремлюють специфічну типологію екскурсій: екскурсії до різних природних об'єктів, виробничі, музейні, комплексні.

У зв'язку 3 поширенням інформаційно-комунікативних технологій досить затребуваними стали віртуальні та інтернет-екскурсії.

Але всі ці класифікації не відповідають вимогам підготовки майбутніх педагогів, які враховували б етапи професійного становлення і форми групової пізнавальної діяльності студентів.

На основі узагальнення різних класифікацій та досвіду практичної діяльності ми запропонували авторську класифікацію. У процесі класифікування види екскурсій ми співвідносили з формами групової пізнавальної діяльності студентів на кожному етапі їхнього професійного становлення (Таблиця 1).

У своїй професійній діяльності ми пропонуємо такі етапи професійного становлення: на початкових курсах - екскурсії до певних географічних об'єктів в межах польових практик; на III-IV курсах - набуття певних знань 3 методики 
організації та проведення екскурсій різного спрямування; на V курсі - перші спроби студентів розроблення екскурсії в умовах туристично-краєзнавчої роботи.

Навчальні екскурсії повинні відповідати певним вимогам:

- Цілевизначеність екскурсії: кожна екскурсія з географії повинна відповідати конкретній меті професійної підготовки майбутнього вчителя географії.

- Наступність змісту: зміст екскурсій повинен мати безпосередній зв'язок із пройденим на попередніх заняттях матеріалом. Водночас, отримані на екскурсіях уявлення, результати спостережень і зібрані матеріали повинні знайти використання на подальших заняттях.

- Професіоналізація змісту: відповідність теми, застосовуваних методів, форм проведення екскурсії аспектам професійної підготовки студентів.

- Послідовність, науковість та чіткість організації та проведення.

У цій класифікації ми пропонуємо різні форми групової пізнавальної діяльності студентів під час навчальних екскурсій з географії, а саме:

- за кількістю студентів: індивідуально-групова (індивідуальна робота здійснюється паралельно чи по черзі з групою), парно-групова, фронтально-групова, групова;

- за характером зв'язку між підгрупами у виконанні навчальних завдань: кооперативно-паралельна (групи одночасно виконують завдання, які в сукупності призводять до досягнення спільного результату), кооперативно-послідовна (групи послідовно виконують завдання, які в сукупності призводять до досягнення спільного результату), змагально-паралельна (групи одночасно виконують однакові чи незначно відмінні завдання, і змагаються у досягненні певного результату за визначеними критеріями) і змагально-послідовна (групи послідовно виконують однакові чи незначно відмінні завдання, i змагаються у досягненні певного результату за визначеними критеріями) види групової навчальної діяльності;

- за тривалістю реалізації: локалізована в межах одного навчального заняття та пролонгована, що відбувається протягом кількох навчальних занять [2].

Таблицяя 1.

Класифікація екскурсій за професійним становленням студентів

\begin{tabular}{|c|c|c|c|c|}
\hline \multirow[b]{2}{*}{ Вид екскурсії } & \multicolumn{3}{|c|}{$\begin{array}{c}\text { Форми групової пізнавальної діяльності } \\
\text { студентів }\end{array}$} & \multirow[b]{2}{*}{$\begin{array}{c}\text { Етапи професійного } \\
\text { становлення } \\
\text { студентів }\end{array}$} \\
\hline & $\begin{array}{l}\text { За кількістю } \\
\text { студентів }\end{array}$ & $\mid \begin{array}{c}\text { За характером } \\
\text { зв'язку між } \\
\text { підгрупами у } \\
\text { виконанні } \\
\text { навчальних } \\
\text { завдань }\end{array}$ & $\begin{array}{c}\text { 3а } \\
\text { тривалістю } \\
\text { реалізації }\end{array}$ & \\
\hline 1 & 2 & 3 & 4 & 5 \\
\hline $\begin{array}{l}\text { Об’сктні } \\
\text { екскурсії } \\
\text { (екскурсії до } \\
\text { певних } \\
\text { географічних } \\
\text { об'єктів, що } \\
\text { вивчаються в } \\
\text { різних курсах } \\
\text { вищої школи) }\end{array}$ & $\begin{array}{c}\text { Індивідуально- } \\
\text { групова; } \\
\text { парно-групова }\end{array}$ & $\begin{array}{l}\text { Змагально- } \\
\text { послідовна }\end{array}$ & Пролонгована & $\begin{array}{l}\text { I-IV курси. Польові } \\
\text { практики з геології, } \\
\text { гідрології, } \\
\text { геоморфології } \\
\text { екологічної практики, } \\
\text { комплексна практика } \\
\text { економічної } \\
\text { соціальної географії }\end{array}$ \\
\hline
\end{tabular}




\begin{tabular}{|c|c|c|c|c|}
\hline 1 & 2 & 3 & 4 & 5 \\
\hline $\begin{array}{l}\text { Методичні } \\
\text { екскурсії } \\
\text { (екскурсії, де } \\
\text { студенти } \\
\text { оволодівають } \\
\text { методикою } \\
\text { організації та } \\
\text { проведення } \\
\text { екскурсій } \\
\text { різного } \\
\text { спрямування) }\end{array}$ & $\begin{array}{c}\text { Фронталь- } \\
\text { но-групова, } \\
\text { групова }\end{array}$ & $\begin{array}{c}\text { Кооперативно- } \\
\text { паралельна }\end{array}$ & Локалізована & $\begin{array}{lr}\text { I-IV курси. } & \text { У } \\
\text { «Мрсах: } \\
\text { «етодика } & \text { навчання } \\
\text { географії», } & \text { «Методика } \\
\text { виховної } & \text { роботи», } \\
\text { «Основи промислового } \\
\text { виробництва», } \\
\text { «Економічна географія } \\
\text { України», «Соціальна } \\
\text { географія } \\
\text { «Основи } \\
\text { ландшаїни», } \\
\text { «Спортознавства», } \\
\end{array}$ \\
\hline $\begin{array}{l}\text { Продуктно- } \\
\text { екскурсійні } \\
\text { (екскурсї, які } \\
\text { здатен } \\
\text { розробити } \\
\text { студент як } \\
\text { екскурсійний } \\
\text { продукт поза } \\
\text { межами } \\
\text { шкільної } \\
\text { програми } \\
\text { умовах } \\
\text { організацї } \\
\text { туристично- } \\
\text { краєзнавчої } \\
\text { роботи) }\end{array}$ & $\begin{array}{c}\text { Фронталь } \\
\text { но-групова, } \\
\text { групова }\end{array}$ & $\begin{array}{c}\text { Кооперативно- } \\
\text { послідовна, } \\
\text { змагально- } \\
\text { послідовна }\end{array}$ & $\begin{array}{l}\text { Локалізована, } \\
\text { пролонгована }\end{array}$ & 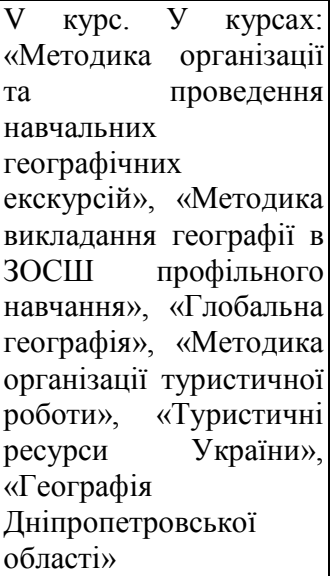 \\
\hline
\end{tabular}

Отже, уважаємо навчальну екскурсію окремим методом і формою навчання та професійної підготовки студентів, не тотожну екскурсійній послузі та польовій практиці, що однак може передбачатися ними для розв'язання певних навчальновиховних чи суспільно-економічних завдань. Навчальні екскурсії з географії можуть бути класифіковані за змістом, витратами часу, місцем у навчально-виховному процесі, місцем проведення, способом пересування, складом учасників, способом організації діяльності, способом організації сприйняття екскурсійного об'єкта. У педагогічному ВНЗ визначають специфічну типологію екскурсій: екскурсії до різних природних об'єктів, виробничі, музейні, комплексні. Головними вимогами до навчальних екскурсій з географії є: цілевизначеність, наступність й професіоналізація змісту, послідовність, науковість та чіткість організації та проведення. До основних методичних прийомів проведення навчальних екскурсій з географії належать: показ, розповідь, навчально-дослідницьке завдання, презентація результатів пізнавальної діяльності студентів у вигляді наукового звіту. Навчальна екскурсія 3 географії дозволяє організувати спостереження та вивчення студентами різних явищ, предметів, процесів у природних умовах, музеях, на виставках тощо, сприяє оволодінню методикою їх організації та проведення, чинить уплив на процес розвитку пізнавальної діяльності студентів. Відтак, посідає важливе місце в системі професійної підготовки, оскільки є формою організації навчально-виховної роботи 3 
географії, засобом становлення професійної компетентності майбутнього вчителя географії.

\section{Література}

1. Ананьев Б. Г. Человек как предмет познания / Б. Г. Ананьев. - [3-е изд.]. СПб. : Питер, 2001. - 288 с. 2. Артюшина М. В. Взаємозв'язок соціальнопсихологічних та дидактичних умов групової навчальної діяльності студентів : автореф. дис. на здобуття наук. ступеня канд. пед. наук : спец. 13.00.04 «Теорія і методика професійної освіти»/ М. В. Артюшина. - К., 2000. - 20 с. 3. Ващенко Г. Загальні методи навчання : [підручник] / Г. Ващенко. - Х. : Держвидав України, 1929. - 232 с. 4. Герд В. А. Экскурсионное дело / В. А. Герд. - М. : Госиздат, 1928. 115 с. 5. Желудковский Е. А. Основы экскурсионного дела : [учеб. пособ.]/ Е. Желудковский, Е. Лукьянова. - Ялта : РИО КГУ, 2008. - 280 с. 6. Куразова Н. Ф. Методика преподавания географии / Н. Ф. Куразова. - М. : Просвещение, 1999. 258 с. 7. Педагогическая энциклопедия / ред. А. И. Каиров, Ф. Н. Петров. - М. : Сов. энцикл., 1964. - Т. 3. - 832 с. 8. Родіна О. П. Групові форми як один із шляхів стимулювання самостійності учнів / О. П. Родіна // Географія. - 2007 - № 8. - С. $17-$ 19.

УДК 378. 147

Олена Драшко

\section{СИСТЕМА ПЕДАГОГІЧНИХ УМОВ ПІДГОТОВКИ ВЧИТЕЛІВ ОБСЛУГОВУЮЧОЇ ПРАЦІ ДО ВИКОРИСТАННЯ ХУДОЖНІХ РЕМЕСЕЛ У НАВЧАЛЬНО-ВИХОВНОМУ ПРОЦЕСІ}

Драшко О. М. Система педагогічних умов підготовки вчителів обслуговуючої праці до використання художніх ремесел у навчально-виховному процесі.

У статті обгрунтувано систему педагогічних умов підготовки вчителів обслуговуючої праці до використання художніх ремесел. Розкрито критерії, показники та рівні підготовки фахівців; етапи впровадження системи обгрунтованих педагогічних умов у навчально-виховний процес ВНЗ 3 підготовки вчителів обслуговуючої праці до використання художніх ремесел у навчально-виховному процесі.

Ключові слова: освітньо-виховний потенціал художніх ремесел, освітньо-виховні функції художніх ремесел; пошуково-творчий, потенційно-можливий, задовільний, недостатній рівні підготовки вчителів обслуговуючої праці до використання художніх ремесел у навчально-виховному процесі.

Драшко Е. Н. Система педагогических условий подготовки учителей обслуживающего труда к использованию художественных ремесел в учебновоспитательном процессе.

В статье обоснована система педагогических условий подготовки учителей обслуживающего труда к использованию художественных ремесел. Раскрыты критерии, показатели и уровни подготовки специалистов, этапы внедрения системы обоснованных педагогических условий в учебно-воспитательный процесс вуза по подготовке учителей обслуживающего труда к использованию художественных ремесел в учебно-воспитательном процессе.

Ключевые слова: образовательно-воспитательный потенциал художественных ремесел; образовательно-воспитательные функции художественных ремесел; поисково-творческий, потенциально-возможный, удовлетворительный, 